\title{
Video Pembelajaran Gerak dan Lagu untuk Menstimulasi Kemampuan Lokomotor Anak Usia 5-6 Tahun
}

\section{Putu Yasri Purnama Dewi ${ }^{*}$, Nice Maylani Asril2 ${ }^{2}$, Dewa Ayu Puteri Handayani3}

\author{
1,2,3 Pendidikan Guru Pendidikan Anak Usia Dini, Universitas Pendidikan Ganesha, Singaraja, Indonesia
}

\section{ART ICLE INFO}

Article history:

Received 27 January 2021

Revised 15 February 2021

Accepted 01 April 2021

Available online 25 April 2021

Kata Kunci:

video gerak dan lagu, lokomotor

Keywords:

motion video and song, locomotor

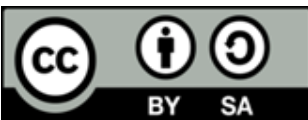

This is an open access article under the CC BY-SA license.

Copyright () Universitas Pendidikan Ganesha. All rights reserved.

\begin{abstract}
A B S T R A K
Permasalahan pada penelitian ini yaitu belum banyaknya media pembelajaran yang mengakibatkan kurang bervariasinya metode pengajaran guru secara daring. Penelitian ini bertujuan untuk mengetahui prosedur pengembangan dan kelayakan video pembelajaran gerak dan lagu untuk anak usia 5-6 tahun. Jenis penelitian yang digunakan yaitu jenis penelitian pengembangan atau Research and Development (R\&D). Subjek penelitian pada penelitian ini yaitu 2 ahli instrumen, 2 ahli materi dan 2 ahli media. Metode pengumpulan data yang digunakan yaitu data kualitatif yang dikoversi menjadi data kuantitatif. Pada penelitian ini menggunakan model pengembangan ADDIE (Analyisis, Design, Development, Implementation, and Evaluation), namun pada penelitian ini tahapan yang dilaksanakan hanya sampai tahap development. Adapun hasil analisis data yaitu nilai CVR adalah 1,00 dan CVI adalah 1,00. Hal ini menunjukkan bahwa skala nilai ini berada di rentang skor 0,80-1,00 yang berarti bahwa validasi isi sangat tinggi. Berdasarkan hasil tersebut, dapat disimpulkan bahwa pengembangan video pembelajaran gerak dan lagu sangat layak digunakan untuk memasuki tahap efektivitas media pada pembelajaran untuk menstimulasi kemampuan lokomotor anak usia 5-6 tahun.
\end{abstract}

A B S T R A C T

The problem in this study is that there are not many learning media which results in less variety of teaching methods for teachers in schools. This study aims to determine the development procedure and feasibility of motion and song learning videos for children aged 5-6 years. The type of research used in this study was the type of research development or Research and Development (R\&D). The research subjects in this study were 2 instrument experts, 2 material experts and 2 media experts. The data collection method used was qualitative data which is converted into quantitative data. In this study using the ADDIE development model (Analysis, Design, Development, Implementation, and Evaluation), but in this study the stages carried out were only up to the development stage. The results of data analysis are the CVR value is 1.00 and CVI is 1.00. This shows that this value scale was in the score range of 0.80-1.00 which means that the content validation is very high. Based on these results, it can be concluded that the development of motion learning videos and songs is very feasible to use to enter the stage of media effectiveness in learning to stimulate the locomotor abilities of children aged 5-6 years.

\section{Pendahuluan}

Keaktifan pada anak usia 5-6 tahun melibatkan gerakan psikomotorik yang meliputi perilaku gerakan dan koordinasi jasmani, keterampilan motorik dan kemampuan fisik seseorang. Artinya, keaktifan inilah yang akan mempengaruhi kemampuan motorik dan pengendalian gerak tubuh. $70 \%-80 \%$ aktivitas yang dominan dilakukakan pada proses belajar anak melibatkan aktivitas bergerak (Farida, 2016; Fitrianti, 2013) Aktivitas bergerak anak berasal dari tahapan pengembangan motorik kasar. Motorik kasar merupakan kematangan diri yang dipengaruhi oleh otot-otot besar yang ada di dalam seluruh anggota tubuh (Andriani, 2019; S. et al., 2020). Motorik kasar anak juga terbagai menjadi tiga

Copyright (C) Universitas Pendidikan Ganesha. All rights reserved 
gerakan dasar yaitu lokomotor, nonlokomotor dan manipulaf (Hidayat, 2017). Gerak lokomotor diartikan sebagai keterampilan gerak yang menyebabkan tubuh dapat berpindah tempat (Lestari et al., 2019; Pradipta, 2017). Gerak nonlokomotor adalah suatu gerakan di tempat tanpa ada ruang gerak seperti melingkar, memutar, mendorong, menarik dan mengangkat (Anugrahana, 2020; Hanief \& Sugito, 2015). Gerak manipulatif adalah gerak yang dikembangkan saat menguasi bermacam objek seperti gerakan mendorong yaitu melempat, memukul, menendang (Hidayat, 2017; MAHMUD, 2019). Dari ketiga gerakan tersebut, gerak lokomotor merupakan gerakan dasar dan umum yang anak kusai sehari-hari.

Namun pada kenyataan di lapangan, masih banyak hambatan yang ditemui. Hal ini dikemukakan oleh salah satu Guru Kelompok B pada observasi dan wawancara tanggal 29-30 Oktober 2020 di TK Apti Guna Widya, Desa Penyaringan, Kecamatan Mendoyo, Kabupaten Jembrana, Bali. Hambatan yang pertama yaitu pembelajaran dilakukan secara daring yaitu learning from home hingga batas waktu yang tidak ditentukan. Selain itu, guru kesulitan merancang kegiatan motorik kasar pada proses pelaksanaan yang ada di rumah. Kemudian, kurangnya pengembangan keterampilan lokomotor selama pembelajaran secara daring. selanjutnya yaitu kurangnya wawasan guru terhadap teknologi pembelajaran. Hambatan yang terakhir yakni guru belum mampu menyediakan media yang mendukung kegiatan motorik kasar anak yaitu gerak lokomotor secara daring. Hal ini juga didukung oleh penelitian anugrahana (2020) bahwa pada proses pembelajran secara daring, guru mengalami kendala pada strategi dalam penyempaian pembelajaran. Selain itu, guru sering mengalami hambatan dalam menyediakan sarana dan prasarana pada proses pembelajaran daring taitu $70 \%$ pada guru di generasi 80 -an (Nopiyanto, 2020). Dari hambatan tersebut maka dapat disimpulkan bahwa masih banyak hambatan untuk pembelajaran daring terutama pada penyediaan sarana dan prasarana seperti media pembelajaran agar mempengaruhi aktivitas belajar jasmani dan aktivitas sehari-hari anak.

Media pembelajaran dapat menjadi alternatif yang baik dalam penyampaian informasi atau pesan yang ingin disampaikan oleh guru kepada peserta didik. Fungsi utama media pembelajaran ialah menyampaikan informasi terkait materi-materi dalam pembelajaran yang ingin disampaikan ke peserta didik (Ahdan et al., 2020; Pabunga \& Saputra, n.d.; Pratiwi \& Puspito Hapsari, 2020). Jadi, perlu dikembangkan media yang dapat diakses dan menjadi panduan untuk anak dapat melaksanakan kegiatan lokomotor walaupun dengan belajar dari rumah atau learning from home. Rancangan media pembelajaran anak harus menarik dan menyenangkan sesuai karakteristik anak dan mampu menyampaikan pesan pembelajaran dalam kegiatan lokomotor anak. Media pembelajaran yang dikembangkan juga harus menyesuaikan dengan kondisi dan perkembangan teknologi yang ada di dalam pendidikan berupa audio visual yaitu video. Video pembelajaran cocok digunakan sebagai media pembelajaran pada kelompok kecil, kelas bahkan individu (Busyaeri et al., 2016). Media dalam bentuk video dapat melatih pendengaran dan penglihatan anak karena video pembelajaran audio visual merupakan perpaduan antara materi visual dan auditif yang menjadikan peserta didik mampu menerima pesan belajar melalui visualisasi dan melalui pendengaran (Nurdin et al., 2019).

Penggunaan media video pembelajaran yang dapat menyampaikan pesan pembelajaran dengan menarik yang dapat menstimulasi kemampuan lokomotor untuk anak usia 5-6 tahun yaitu menggunakan video gerak dan lagu. Penggunaan musik sebagai media diantaranya karena musik membantu untuk berolahraga. Hal ini dudukung oleh pernyataan bahwa musik dapat mendukung ketahanan dalam berolahraga (Anggriawan, 2015; Ningsih, 2013). Kemudian musik dapat meningkatkan kemampuan motorik dan keterampilan. Selain itu, Musik dapat mempengaruhi mimik wajah. Selanjutnya musik dapat meningkatkan kreativitas (Wijirahayu \& Syarif, 2019). Dengan demikian, media video gerak dan lagu dapat digunakan sebagai media pembelajaran dalam menstimulasi kemampuan lokomotor. Pada konsep pembelajaran gerak dan lagu termasuk di kegiatan yang mudah dikembangkang berdasarkan aspek perkembangan, mudah diterapkan, simpel, dan mampu meningkatkan kemampuan atau kecerdasan kinestetik pada anak (Mulyani, 2019; Prahesti et al., 2019). Penggunaan video pembelajaran maka dapat dijadikan alternatif dalam menerapkan pembelajaran yang dilaksanakan pada pembelajaran daring ini. Adapun tujuan pada penelitian ini yaitu untuk mengetahui pengembangan video pembelajaran pembelajaran dan menghasilkan video gerak dan lagu yang layak untuk menstimulasi kemampuan lokomotor anak usia 5-6 tahun. Adanya video pembelajaran gerak dan lagu ini dalam pelaksanaan pembelajaran, guru maupun orang tua diharapkan mampu memahami petunjuk penggunaan media video pembelajaran gerak dan lagu agar dapat terlaksana aktivitas belajar yang optimal sehingga tujuan pembelajaran untuk stimulasi kemampuan lokomotor tercapai.

\section{Metode}

Jenis penelitian yang digunakan pada penelitian ini yaitu jenis penelitian pengembangan atau Research and Development (R\&D). Penyusunan penelitian ini dilaksnakan dengan sistem yang sistematis 
untuk pemecahan masalah yang sesuai dengan kebutuhan dalam karakteristik proses pembelajaran (Tegeh et al., 2015). Maka dari itu, pada penelitian ini yaitu mengembangkan media pembelajaran berupa video pembelajaran gerak dan lagu untuk kemampuan motorik kasar yaitu gerak lokomotor anak usia 5-6 tahun. Model pengembangan yang digunakan yaitu model pengembangan ADDIE terdapat lima tahap pengembangan, yaitu: analisis (analysis), perancangan (design), pengembangan (development), implementasi (implementation), dan evaluasi (evaluation), tahapan ini dijelaskan oleh (Cahyadi, 2019; Carolin et al., 2020). Namun, tahapan pelaksanaan pengembangan hanya sebatas uji kelayakan media oleh ahli media dan ahli materi. Hal ini dikarenakan kondisi pandemi COVID-19 yang belum memungkinkan untuk melakukan uji coba kepada peserta didik. Tahapan tersebut dapat dilihat pada gambar di bawah (Tegeh \& Kirna, 2013). Dapat dilihat pada gambar 1.

Subjek penelitian pada penelitian ini adalah 2 ahli instrumen, 2 ahli media dan 2 ahli materi. Ahli instrumen yang dimaksud yaitu dosen yang mengetahui dan menguasi materi yang terkait dengan perkembangan motorik dan gerak lokomotor anak untuk usia 5-6 tahun. Ahli instrumen berperan untuk mengarahkan kesesuaian materi gerak lokomotor usia 5-6 tahun dengan produk video gerak dan lagu yang dirancang. Sedangkan yang dimaksud dari ahli materi dan media yakni dosen yang paham dibidang teknologi pembelajaran dan pendidikan. Ahli materi dan media berperan untuk memberikan arahan dan penilaian mengenai kelayakan media untuk digunakan oleh anak usia 5-6 tahun. Metode pengumpulan data yang digunakan yaitu wawancara, observasi dan kuesioner. Wawancara digunakan sebagai teknik pengumpulan data untuk menemukan permasalahan yang akan diteliti dan informasi secara mendalam dengan jumah responden yang sedikit (Sugiyono, 2017). Observasi merupakan teknik pengumpulan data yang dilakukan dengan mengamati secara langsung yang ada di lapangan (Sugiyono, 2017). Kuesioner dapat digunakan untuk memperoleh sebuah informasi yang berkaitan dengan sikap, opini, harapan dan keinginan dalam bentuk pertanyaan kepada responden (Neyfa \& Tamara, 2016). Proses wawancara dilakukan guna memperoleh data pada proses pembelajaran yang bersifat terbuka pada kegiatan yang dilaksanakan dan memperoleh kebutuhan yang diperlukan pada pelaksanaan pembelajaran daring. Proses observasi dilaksanakan untuk mengamati secara langsung dan mengetahui sistematis kelengkapan sarana dan prasarana serta proses rencana pelaksanaan pembelajaran secara daring seperti aspek pembelajaran, metode pembelajaran, penggunaan media pembelajaran, respon pesrta didik dan media pendukung pada keterampilan lokomotor. Sedangkan kuesioner bertujuan untuk mendapatkan hasil dari kesesuaian materi dan kelayakan media berupa nilai dan saran terhadap media video gerak dan lagu yang sudah dibuat oleh peneliti. Adapun hasil dari kuesioner ini berupa kuesioner lembar validasi pembelajaran dengan dimensi berjalan, melompat, meloncat dan berlari seperti tabel 1 ini.

Tabel 1. Kisi-kisi Instrumen Gerak Lokomotor untuk Anak Usia 5-6 Tahun

\begin{tabular}{|c|c|c|c|c|}
\hline No. & Dimensi & Indikator & Butir & Jumlah \\
\hline 1. & Berjalan & $\begin{array}{l}\text { 1. Berjalan yang teratur ke depan. } \\
\text { 2. Berjalan mundur dengan seimbang. } \\
\text { 3. Berjalan dengan gerakan dan arah } \\
\text { yang lincah. }\end{array}$ & $1,2,3$ & 3 \\
\hline 2. & Melompat & $\begin{array}{l}\text { 1. Melompat dengan mengangkat satu } \\
\text { kaki. } \\
\text { 2. Mendarat menggunakan kedua kaki } \\
\text { saat melompat. }\end{array}$ & 4,5 & 2 \\
\hline 3. & Meloncat & $\begin{array}{l}\text { 1. Meloncat dengan kedua kaki. } \\
\text { 2. Menurunkan kedua kaki secara } \\
\text { bersamaan saat meloncat }\end{array}$ & 6,7 & 2 \\
\hline 4. & Berlari & $\begin{array}{l}\text { 1. Berlari pada saat aba-aba berlari. } \\
\text { 2. Berhenti pada saat aba-aba berlari. }\end{array}$ & 8,9 & 2 \\
\hline \multicolumn{3}{|c|}{ Jumlah Item } & & 9 \\
\hline
\end{tabular}

Metode analisis data pada penelitian ini yaitu menggunakan analisis data kualitatif yang dikonversi menjadi analisis data kuantitatif. Informasi akan dikelompokkan yaitu berupa data kualitatif yang didapat dari informan berupa tanggapan, kritik, saran dan revisi produk pengembangan video gerak dan lagu. Data tersebut diperoleh pada tahap analisis kebutuhan anak dan pada tahap implementasi produk. Langkah-langkah yang digunakan pada teknik analisis data kualitatif yaitu pengumpulan data, reduksi data, penyajian data dan kesimpulan. Dari data kualitatif tersebut, dilanjutkan dengan analisis data secara kuantitatif dengan analisis validasi instrumen dan analisis validasi media dan materi. Analisis instrumen menggunakan validasi konstruksi (construct validity) 
didukung dengan pendapat para ahli (judgment experts) dilanjutkan dengan penilaian matriks tabulasi silang, dan perhitungan validasi isi. Sedangkan validasi media dan materi menggunakan rumus Content Validity Ratio (CVR) dan melakukan perhitungan rata-rata menggunakan rumus Content Validaty Index (CVI) (Srirahayu \& Arty, 2018).

\section{Hasil dan Pembahasan}

Penelitian ini menghasilkan produk berupa pengembangan media pembelajaran dalam bentuk video gerak dan lagu untuk menstimulasi kemampuan lokomotor anak usia 5-6 tahun. Hasil dari produk ini dipaparkan berdasarkan prosedur pembuatan video pembelajaran dan kelayakan media untuk dapat digunakan dilapangan oleh guru. Media ini jua dibuat sebagai alternatif media pembelajaran yang diberikan pendidik untuk anak usia 5-6 tahun pada kegiatan pembelajaran di sisitem pembelajaran saring maupun luring. Adapun hasil dari tahap penelitian pengembangan video gerak dan lagu yaitu sebagai berikut. Tahap analisis (analysis). Pada tahap ini guru memerlukan media pembelajaran dalam mengembangkan gerak lokomotor pada proses belajar secara daring. Hal ini dikarenakan guru sulit untuk mengembangkan kegiatan-kegiatan pembelajaran secara daring sehingga belum adanya pengembangan media yang mendukung pembelajaran untuk kegiatan lokomotor anak usia 5-6 tahun pada pembelajaran secara daring. Pada proses pembelajaran, guru jarang menerapkan kegiatan-kegiatan lokomotor selain kegiatan senam yang dilakukan di sekolah pada kegiatan tatap muka. Selain itu pula, belum adanya media dalam mesntimulasi kemampuan lokomotor anak pada pembelajaran daring. Maka, pada penelitian ini memerlukan teori mengenai unsur-unsur pada perkembangan motorik kasar, karakteristik anak usia 5-6 tahun, dan kemampuan gerak lokomotor yang dimiliki anak usia 5-6 tahun seperti kegiatan berlari, berjalan, melompat dan meloncat. Tahap perancangan (design). Media ini dirancang dengan konsep pengembangan gerak dan lagu. Pada tahapan ini pula, dirancang spesifikasi produk mengenai desain, model tampilan, audio-visual dan kebutuhan materil. Desain pada media ini dilaksanakan dengan beberapa tahap seperti desain bagan utama (flowchart), perancangan storyboard, record, penyusunan naskah dan pembuatan media. Gerakan seperti berlari, berjalan, melompat dan meloncat dirancang berdasarkan unsur-unsur dasar dalam gerakan seperti kecepatan, power, ketahanan, kelincahan, keseimbangan, kekuatan, fleksibilitas dan koordinasi.

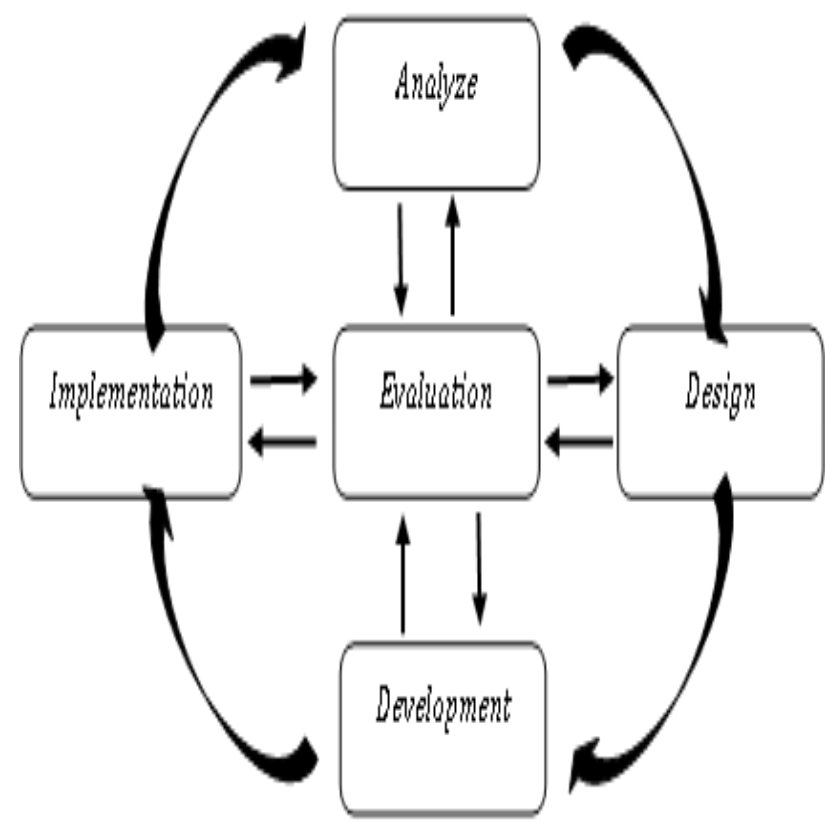

Gambar 1. Tahapan ADDIE

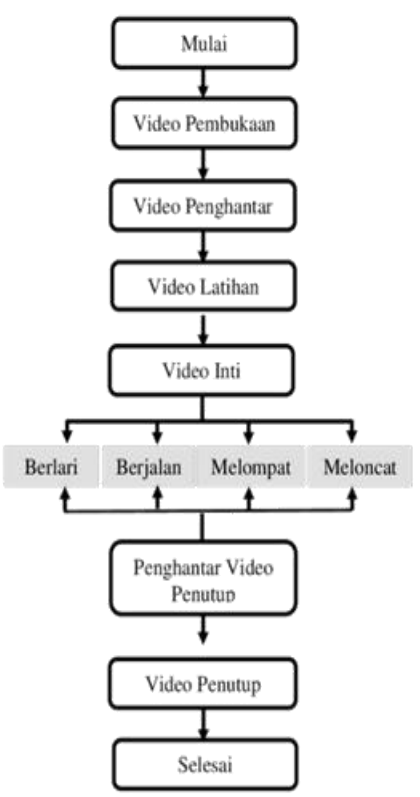

Gambar 2. Desain flowchart 


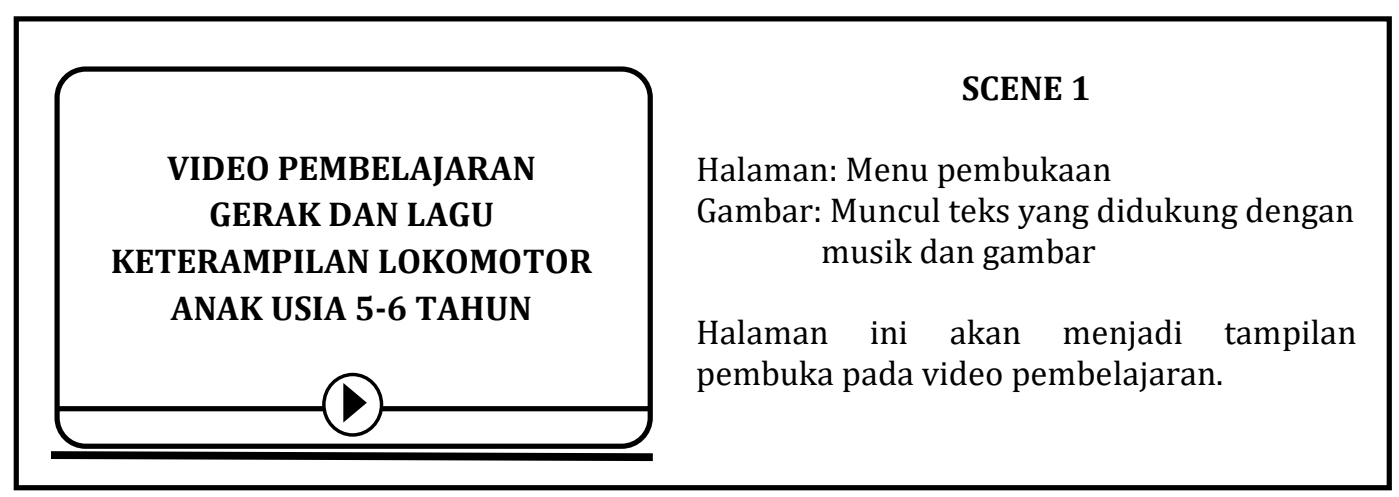

Gambar 3. Storyboard pembukaan

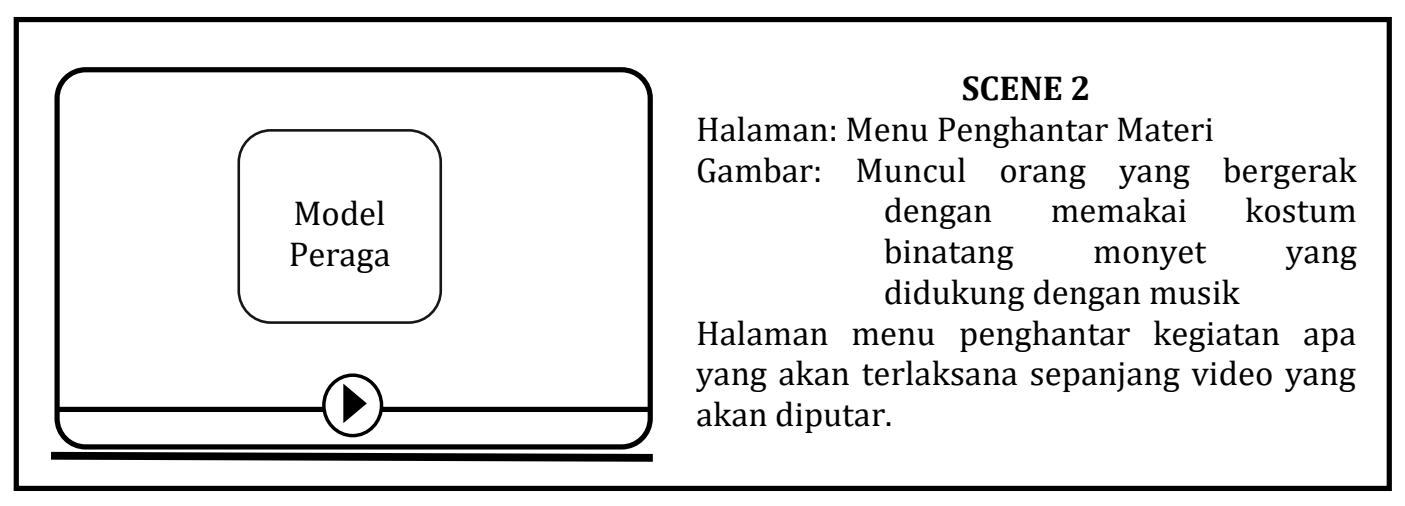

Gambar 4. Storyboard Menu Penghantar Materi

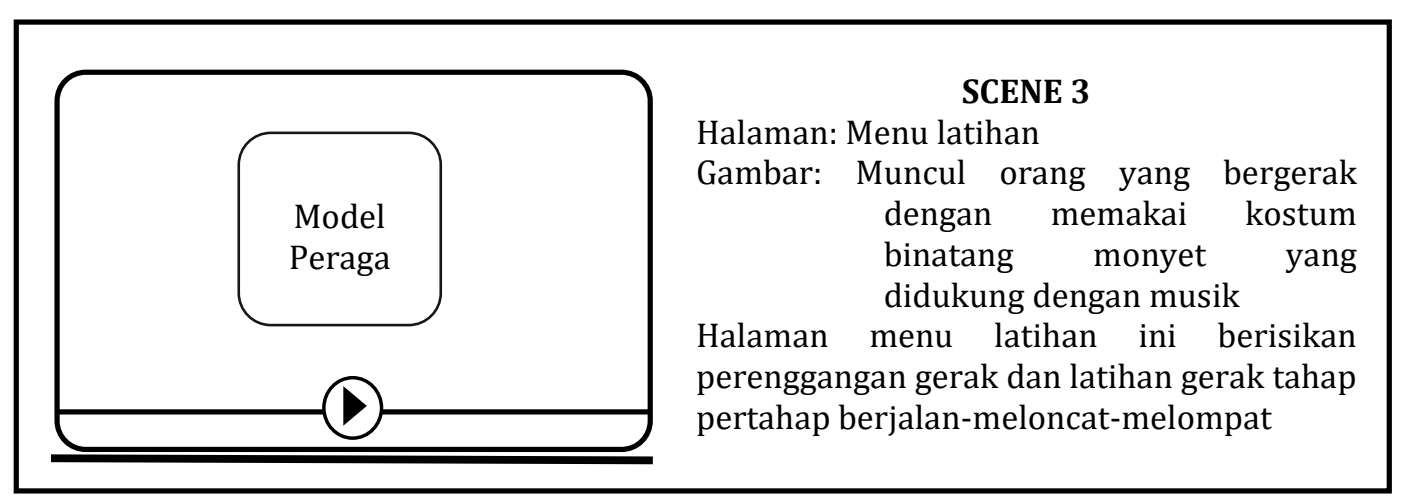

Gambar 5. Storyboard Menu latihan

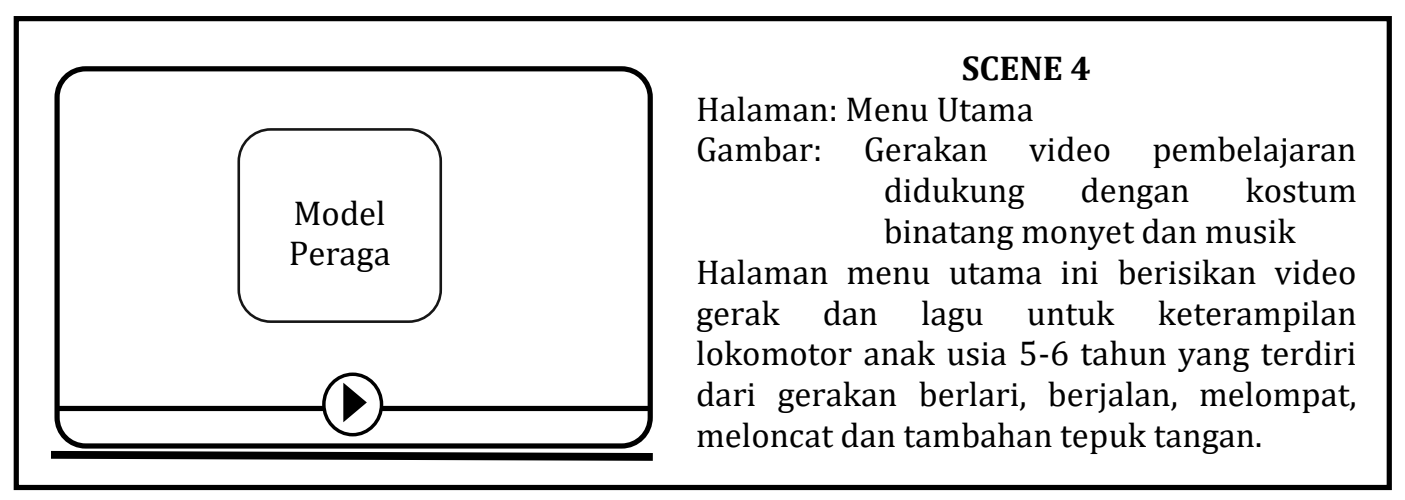

Gambar 6. Storyboard Menu Utama 


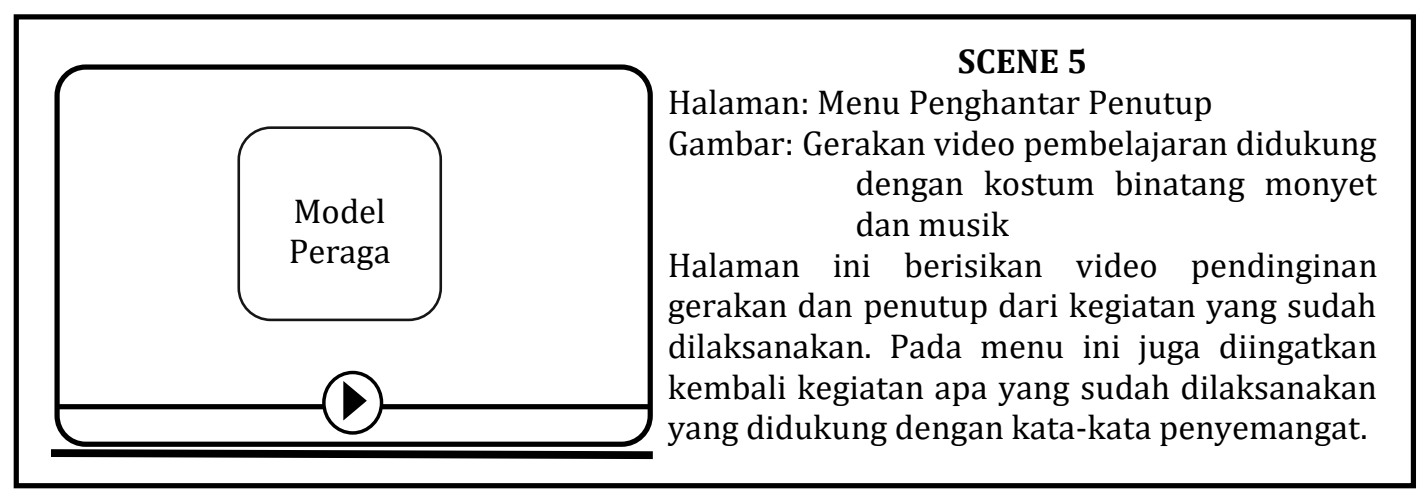

Gambar 7. Storyboard Penghantar Penutup

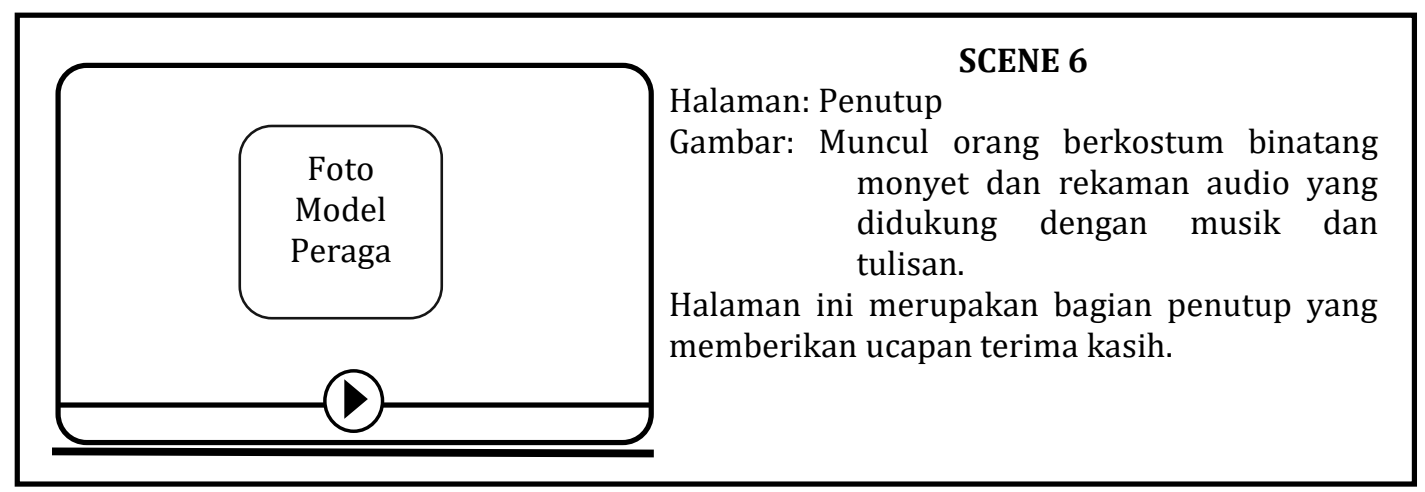

Gambar 8. Storyboard Penutup

Tahap pengembangan (development). Agar mendapatkan pengembangan media yang layak, maka harus dilakukan proses penilaian oleh ahli yang meliputi 2 pembanding dari dosen ahli dibidangnya pada setiap tahap uji instrumen, media maupun materi. Penilaian dilakukan dengan tahap validasi dan revisi yang diberikan oleh kedua ahli media dalam penyempurnaan media pembelajaran gerak dan lagu. Tahap revisi dilakukan untuk mengetahui relevan instrumen dan kelayakan media untuk penyempurnaan video yang sudah dirancang. Adapun saran pada media ini oleh ahli yaitu agar memperjelas gerakan yang akan dilaksanakan, dapat ditambahkan title dan tambahkan juga panduan penggunaan video pembelajaran. Sedangkan pada tampilan video dapat ditambahkan tampilan tulisan pembukaaan dan ucapan terima kasih. Dari tahap revisi tersebut di dapatkan hasil validasi data yang diperoleh dari penilaian yang telah dinilai dari kedua ahli pada materi media video pembelajaran gerak dan lagu adalah nilai CVR adalah 1 dan CVI adalah 1 dengan 8 butir pertanyaan pada instrumen materi dan 8 butir pertanyaan pada instrumen media. Dari penilaian tersebut maka mendapat koefesien 0,80-1,00 yang menyatakan bahwa validasi isi sangat tinggi. Dari perhitungan tersebut maka video pembelajaran gerak dan lagu ini sangat layak untuk digunakan. Setelah memperoleh hasil penilaian untuk validasi kelayakan media video gerak dan lagu, maka dilakukan perbaikan dan tambahan item di tampilan video. Adapun hasil dari pengembangan media gerak dan lagu berdasarkan prosedur desain dan uji media, berikut merupakan hasil akhir tampilan video gerak dan lagu
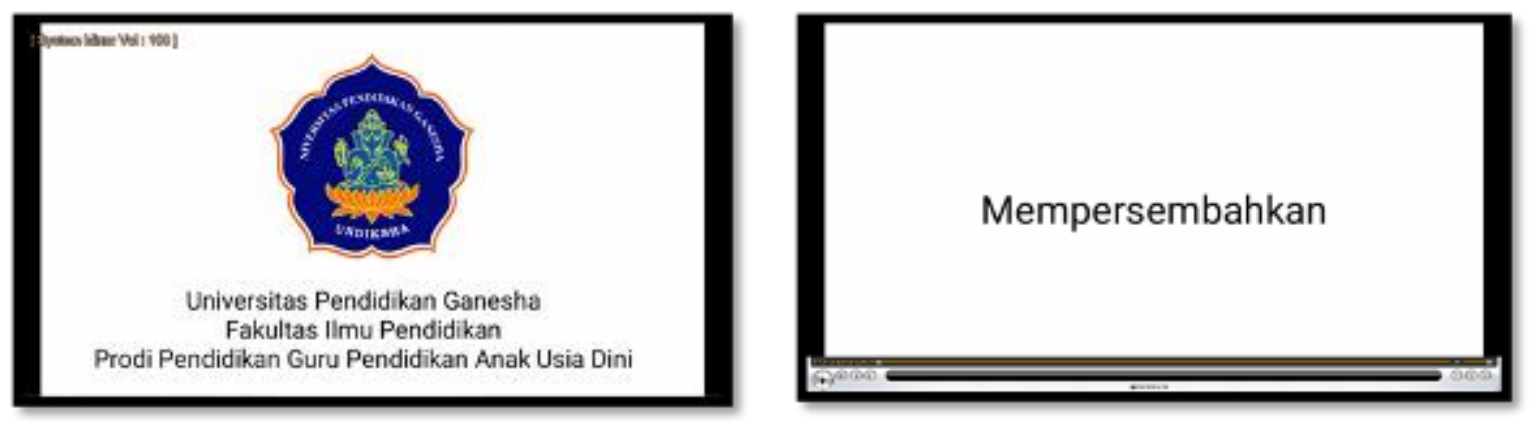

Gambar 9. Tampilan Video Pembukaan 

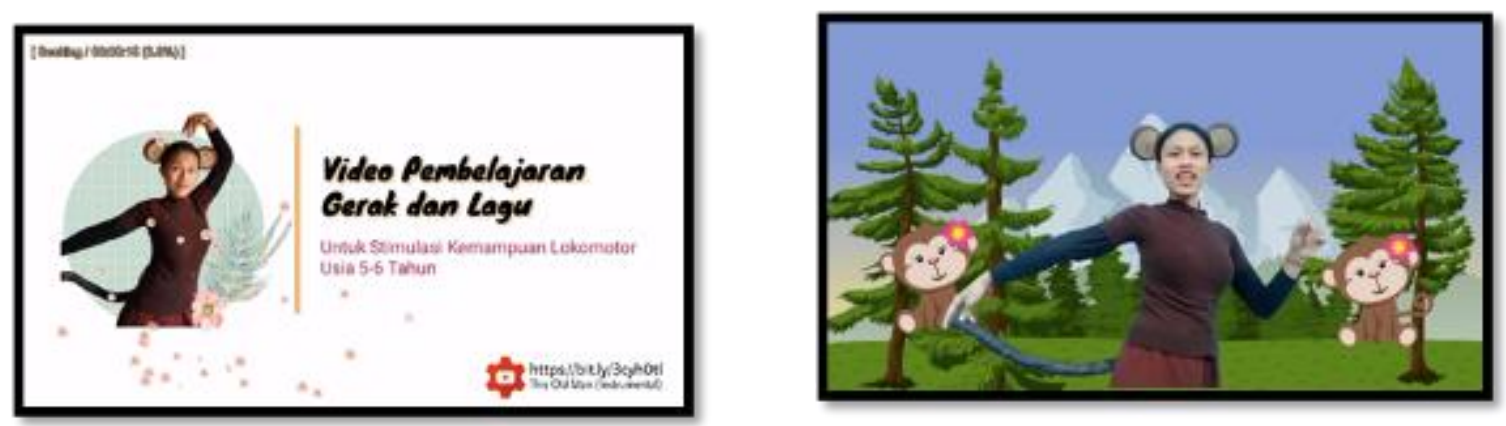

Gambar 10. Tampilan Video Penghantar Video
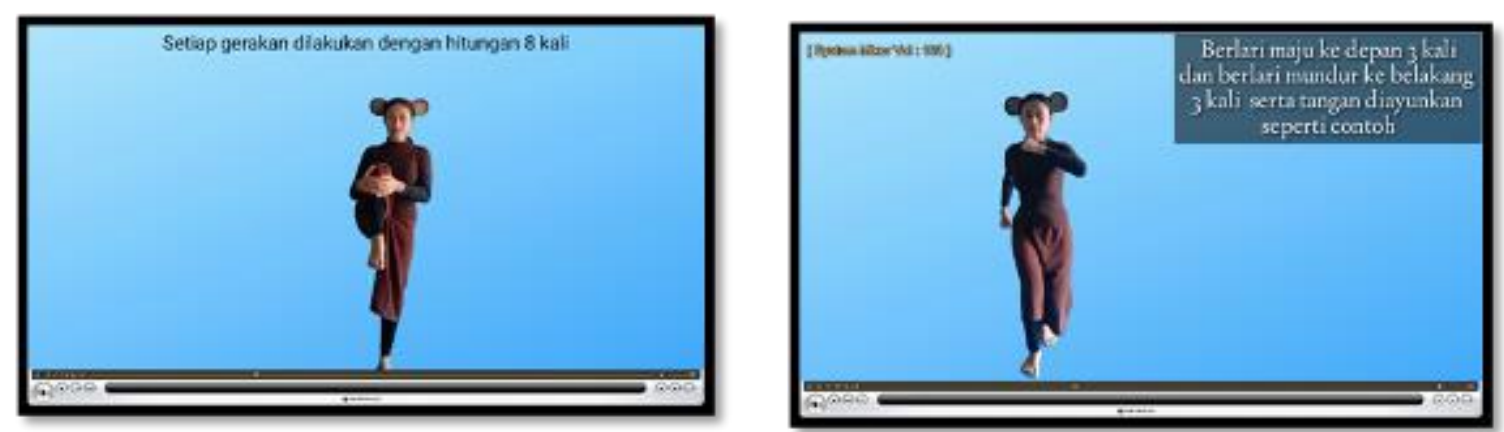

Gambar 11. Tampilan Video Pemanasan dan Latihan gerakan
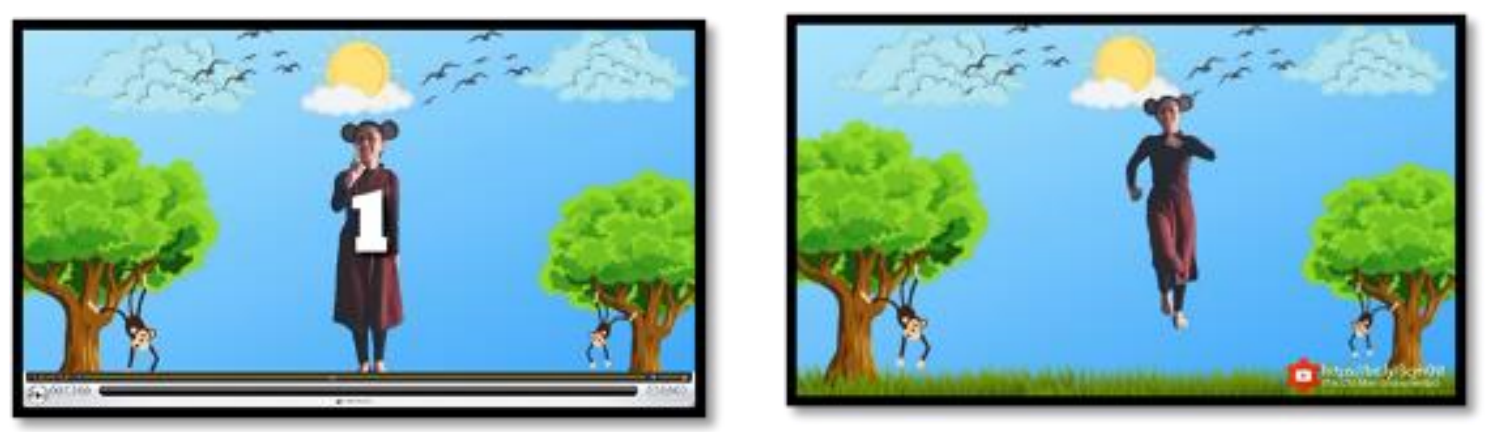

Gambar 12. Tampilan Video Inti Gerakan
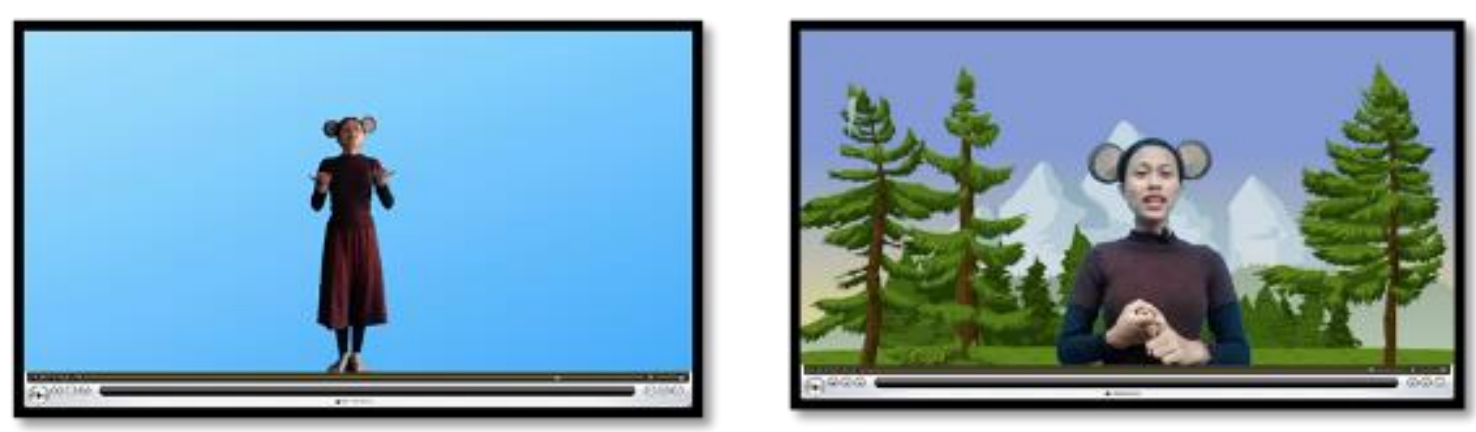

Gambar 13. Tampilan Pendinginan Gerakan dan Penghantar Penutup 

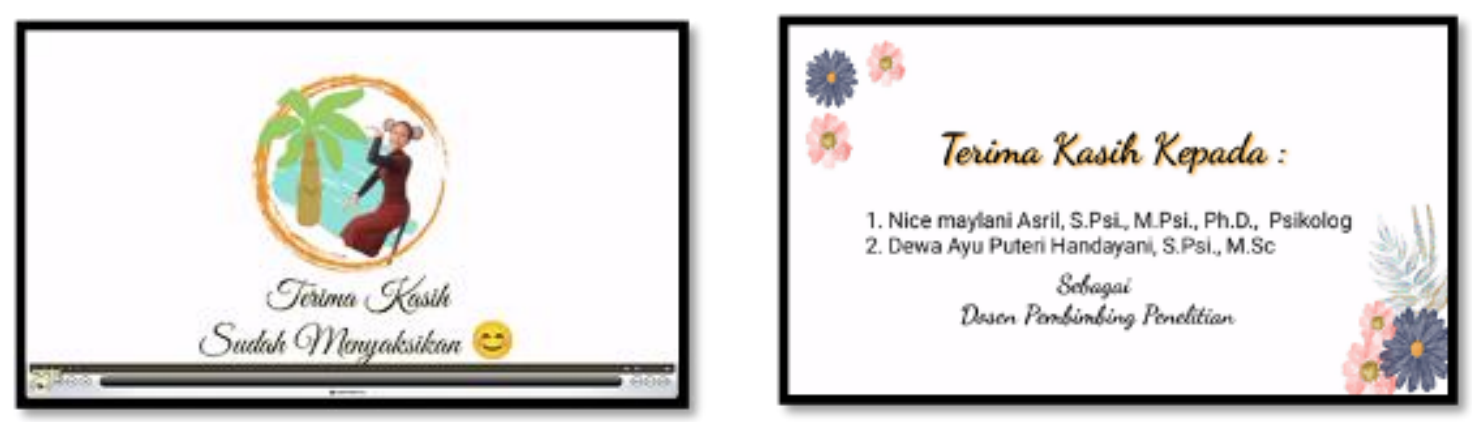

Gambar 14. Tampilan Video Penutup

Pengembangan produk ini juga didukung dengan panduan penggunaan media dan langkahlangkah gerakan. Panduan ini membantu guru dalam menerapkan video pembelajaran gerak dan lagu kepada peserta didik.
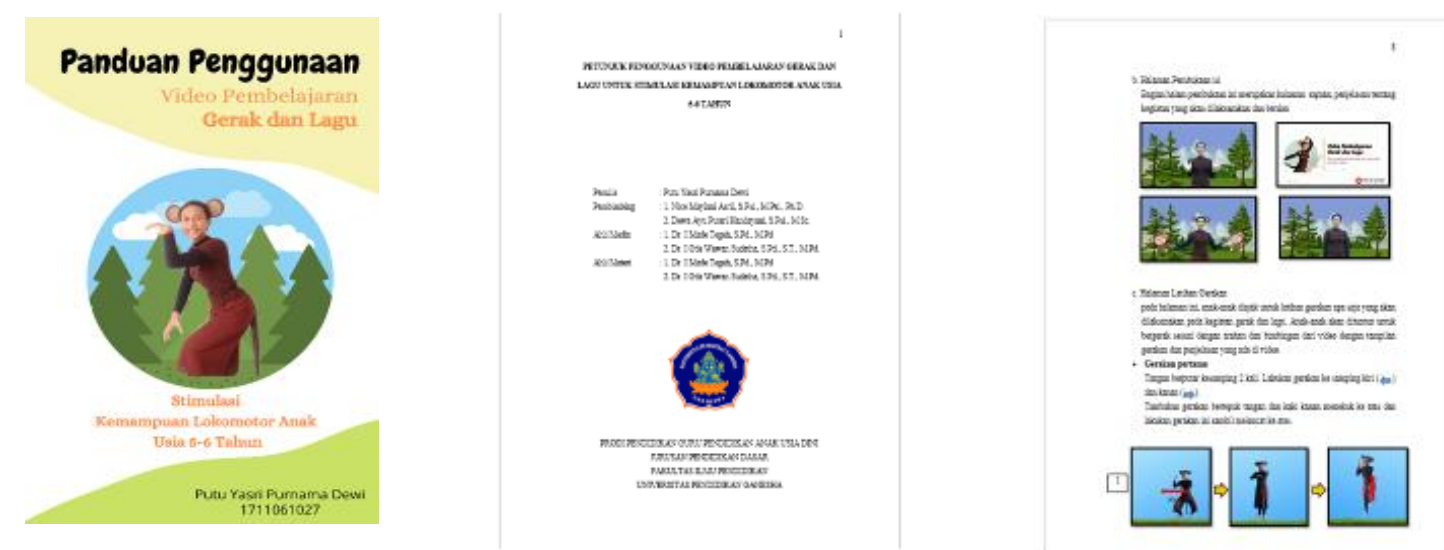

Gambar 15. Panduan Penggunaan Video Pembelajaran

Berdasarkan hasil analisis data yang telah dilakukan maka media video pembelajaran gerak dan lagu mendapatkan kualifikasi sangat baik, sehingga layak untuk diterapkan dalam proses pembelajaran. Media video pembelajaran gerak dan lagu ini wajib dikembangkan karena media pembelajaran video ini dapat memfasilitasi untuk melatih kemampuan lokomotor anak. Selain itu, adanya media pembelajaran ini juga dapat membantu guru dalam melatih anak untuk mengembangkan kemampuan lokomotornya. Media video pembelajaran ini mendapatkan kualifikasi sangat baik dan layak diterapkan disebabkan oleh beberapa faktor yaitu sebagai berikut.

Pertama, terlaksananya penelitian ini diharapkan dapat menghasilkan produk untuk melatih kemampuan lokomotor anak yang sesuai dengan kebutuhan guru di lapangan dan kondisi pelaksanaan pembelajaran. Pelaksanaan pembelajaran secara daring ini dapat menjadi alternatif penerapan media pembelajaran yang dapat menyampaikan pesan dan informasi pada kegiatan motorik kasar anak terutama pada kegiatan gerak dasar lokomotor seperti berjalan, berlari melompat dan meloncat. Materi yang digunakan pada pembelajaran ini menyesuaikan dengan kompetensi dasar dan tahapan usia 5-6 tahun untuk kelompok B yang nantinya dapat melaksanakan gerakan secara sistematis dan kompleks. Gerakan yang yang telah digunakan pada video pembelajaran meliputi stimulasi-stimulasi dalam unsurunsur gerakan motorik kasar seperti gerakan berjalan yang teratur ke depan melatih kemampuan unsur ketahanan, kelincahan dan keseimbangan. Gerakan berjalan mundur dengan seimbang melatih kemampuan unsur ketahanan, kelincahan dan keseimbangan. Gerakan berjalan dengan gerakan dan arah yang lincah melatih kemampuan unsur ketahanan, kelincahan dan keseimbangan. Gerakan melompat dengan mengangkat satu kaki melatih kemampuan koordinasi gerakan keseimbangan, kelincahan, dan power. Kegiatan lokomotor anak dapat meningkatkan motorik kasar anak pada aspek keseimbangan, kelincahan, dan ketahanan anak secara signifikan (Hanief \& Sugito, 2015; Wulandari et al., 2021)

Kedua, produk yang dihasilkan pada pengembangan ini yaitu dengan menggunakan tema binatang monyet yang lucu. Tampilan ini didukung dengan konstum dan aksesoris seperti bando telinga 
monyet dan ekor monyet. Media yang menarik perhatian anak agar bersemangat dan tertarik untuk mengikuti gerak lokomotor. Selain pada tampilan dan tema, produk ini ditampilkan untuk media pembelajaran dalam bentuk video gerak dan lagu. Video gerak dan lagu ini dapat menjadi alternatif guru untuk menerapkan pembelajaran dan mengembangkan keterampilan gerak lokomotor anak. media video ini dibuat dengan pemilihan tampilan video dan lagu yang ceria dan membangkitkan semangat anak sehingga sangat cocok untuk pelaksanaan kegiatan lokomotor anak usia 5-6 tahun. Anak lebih fokus mengikuti proses pembelajaran yang melibatkan media, guru dan komponen dalam video seperti gambar dan audio (Rose et al., 2016; Wuryanti, 2016). Menggunakan pembelajaran gerak dan lagu berbantuan audiovisual dapat meningkatkan kecerdasan kinestetik yang tampak pada peningkatan kecerdasan kinestetik yang dilakukan di kelompok B (Pendidikan et al., 2016).

Temuan penelitian sebelumnya mengenai video pembelajaran juga menyatakan bahwa video dapat meningkatkan semangat siswa (Apriansyah, 2020; Hasmira et al., 2017; Wuryanti \& Kartowagiran, 2016). Temuan penelitian lain juga menyatakan media video binatang dapat berpengaruh terhadap perkembangan motorik kasar anak (Media et al., 2009; Nurdin et al., 2019). Rancangan dan pengembangan produk ini, terdapat keterbatasan pelaksanaan dan penerapan tahap uji coba produk. Hal ini dikarenakan kondisi pandemi COVID-19 yang menyebabkan terbatasnya peneliti dalam melanjutkan penelitian hingga tahap implementasi dan evaluasi produk. Dari keterbatasan tersebut, peneliti belum dapat memaparkan mengenai keefektivitasan media pembelajaran dalam menstimulasi kemampuan lokomotor anak usia 5-6 tahun.

\section{Simpulan}

Media yang dikembangkan pada penelitian ini mendapatkan perolehan kategori sangat layak untuk digunakan. Hal ini dapat dilihat dari aspek kebutuhan media, pengembangan media, media yang relevan untuk digunakan, kesesuaian materi, konsep gerakan, efesiensi penggunaan video dan kualitas tampilan video. Namun, pada penelitian ini hanya sebatas uji kelayakan media yaitu pada tahap pengembangan produk. Maka dari itu, media ini dapat direkomendasikan untuk tahap efektivitas penggunaan media di lapangan dalam menstimulasi kemampuan lokomotor untuk anak usia 5-6 tahun. Diharapkan dengan adanya media ini, pendidik dapat memfasilitasi kemampuan lokomotor anak dan kepada peneliti lain semoga penelitian ini dapat menjadi acuan pengembangan penelitian selanjutnya

\section{Daftar Rujukan}

Ahdan, S., Putri, A. R., \& Sucipto, A. (2020). Aplikasi M-Learning Sebagai Media Pembelajaran Conversation Pada Homey English. Sistemasi, 9(3), 493. https://doi.org/10.32520/stmsi.v9i3.884.

Andriani, E. Y. (2019). Pengembangan Media Pembelajaran Video Animasi Dan Hasil Belajar Di Sekolah Dasar ( The Development of Animation Video Learning Media to Increase High Order Thinking Skills and Learning Outcomes in Primary School ). Jurnal Teknologi Pendidikan Dan Pembelajaran, 509, 3136.

Anggriawan, N. (2015). Peran Fisiologi Olahraga Dalam Menunjang Prestasi. Jurnal Olahraga Prestasi, 11(2), 114694. https://doi.org/10.21831/jorpres.v11i2.5724.

Anugrahana, A. (2020). Hambatan, Solusi dan Harapan : Pembelajaran Daring Selama Masa Pandemi Covid-19 Oleh Guru Sekolah Dasar. Jurnal Pendidikan Dan Kebudayaan, 10(3), 282-289. https://doi.org/10.24246/j.js.2020.v10.i3.p282-289.

Apriansyah, M. R. (2020). Pengembangan Media Pembelajaran Video Berbasis Animasi Mata Kuliah Ilmu Bahan Bangunan Di Program Studi Pendidikan Teknik Bangunan Fakultas Teknik Universitas Negeri Jakarta. Jurnal PenSil, 9(1), 9-18. https://doi.org/10.21009/jpensil.v9i1.12905.

Busyaeri, A., Udin, T., \& Zaenudin, A. (2016). Pengaruh Penggunaan Video Pembelajaran Terhadap Peningkatan Hasil Belajar Mapel Ipa Di Min Kroya Cirebon. Jurnal Pendidikan Guru MI, 3(1), 116137. https://doi.org/10.24235/al.ibtida.snj.v3i1.584.

Cahyadi, R. A. H. (2019). Pengembangan Bahan Ajar Berbasis Addie Model. Halaqa: Islamic Education Journal, 3(1), 35. https://doi.org/10.21070/halaqa.v3i1.2124.

Carolin, L. L., Astra, I. K. B., \& Suwiwa, I. G. (2020). Jurnal Kejaora : Jurnal Kesehatan Jasmani dan Olah Raga. Jurnal Kesehatan Jasmani Dan Olahraga, 5(2), 12-18. https://doi.org/10.36526/kejaora.v5i2.931.

Farida, A. (2016). Urgensi Perkembangan Motorik Kasar pada Perkembangan Anak Usia Dini. Jurnal Raudhah, 4(2), 10-38. https://doi.org/10.30829/raudhah.v4i2.52.

Fitrianti, D. (2013). Mengembangkan Kegiatan Gerak Dan Lagu Untuk Meningkatkan Kemampuan Motorik Kasar Pada Anak Usia 5-6 Tahun. PAUD Teratai, 2(3), 1-6. 
Hanief, Y. N., \& Sugito, S. (2015). Membentuk Gerak Dasar Pada Siswa Sekolah Dasar Melalui Permainan Tradisional. Jurnal SPORTIF: Jurnal Penelitian Pembelajaran, 1(1), 60-73. https://doi.org/10.29407/js_unpgri.v1i1.575.

Hasmira, Anwar, \& Yusuf, M. (2017). Penggunaan Media Pembelajaran Video Animasi untuk Meningkatkan Hasil Belajar PKn pada Siswa kelas Kelas IV di SD Negeri 1 Ngapa. Jurnal Wahana Kajian Pendidikan IPS, 1(2), 128-137. https://doi.org/10.33772/jwkp-ips.v1i2.7452.

Hidayat, A. (2017). Peningkatan Aktivitas Gerak Lokomotor, Nonlokomotor Dan Manipulatif Menggunakan Model Permainan Pada Siswa Sekolah Dasar. Jurnal Pendidikan Jasmani Dan Olahraga, 2(2), 21. https://doi.org/10.17509/jpjo.v2i2.8175.

Lestari, E., Muslihin, H. Y., \& Mulyana, E. H. (2019). Balap Karung Mengambil Bola Di Kelompok B Tk Negeri Pembina Kota Tasikmalaya. 3(1), 1-10. https://doi.org/10.17509/jpa.v3i1.26662.

MAHMUD, B. (2019). Urgensi Stimulasi Kemampuan Motorik Kasar Pada Anak Usia Dini. DIDAKTIKA: Jurnal Kependidikan, 12(1), 76-87. https://doi.org/10.30863/didaktika.v12i1.177.

Media, P., Binatang, V., Motorik, T., Anak, K., Permata, T. K., \& Surabaya, B. (2009). Pengaruh Media Video Binatang Terhadap Motorik Kasar Anak Kelompok A Tk Permata Bunda Surabaya Hayatun Nufus Azizah PG PAUD, Fakultas Ilmu Pendidika, Universitas Negeri Surabaya, Email: hanufazizah@gmail.com Sri Setyowati PG PAUD , Fakultas Ilmu Pend.

Mulyani, N. (2019). Pengembangan Kreativitas Anak Usia Dini Melalui Bermain Gerak Dan Lagu Di TK Negeri Pembina Kabupaten Purbalingga. As-Sibyan: Jurnal Pendidikan Anak Usia Dini, 4(1), 13-24. https://doi.org/10.32678/as-sibyan.v4i1.1961.

Neyfa, B. C., \& Tamara, D. (2016). Perancangan Aplikasi E-Canteen Berbasis Android Dengan Menggunakan Metode Object Oriented Analysis \& Design ( OOAD ). British Medical Journal, 1(6001), 107-109. https://doi.org/10.1136/bmj.1.6001.107.

Ningsih, E. (2013). Penggunaan Metode Bermain Peran Dalam Menumbuhkan Keterampilan Berbahasa Anak Usia Dini. Journal of Chemical Information and Modeling, 53(9), 1689-1699.

Nopiyanto. (2020). Hambatan Guru Pendidikan Jasmani Generasi 80-An Dalam Pembelajaran Daring Di Tengah Pandemi COVID-19. Jurnal Sporta Saintika, 5(September), 139-148. https://doi.org/ 10.24036/sporta.v5i2.140.

Nurdin, E., Ma'aruf, A., Amir, Z., Risnawati, R., Noviarni, N., \& Azmi, M. P. (2019). Pemanfaatan video pembelajaran berbasis Geogebra untuk meningkatkan kemampuan pemahaman konsep matematis siswa SMK. Jurnal Riset Pendidikan Matematika, 6(1), 87-98. https://doi.org/10.21831/jrpm.v6i1.18421

Pabunga, D. B., \& Saputra, H. N. (n.d.). ( TRAINING OF BLOG DEVELOPMENT AS A MEDIUM IN VOCATIONAL LEARNING ) Jurnal Berdaya Mandiri. 1, 336-344. https: //doi.org/ 10.31316/jbm.v2i2.655.

Intan, A. A. I., Lastari, A., Gading, I. K., Antara, P. A., (2016). Audiovisual Untuk Meningkatkan Kecerdasan Kinestetik Pada Anak Kelompok B. E-Journal Pendidikan Anak Usia Dini Iniversitas Pendidikan Ganesha, 4(2), 1-10. https://doi.org/10.23887/paud.v4i2.7703.

Pradipta, G. D. (2017). Strategi Peningkatan Keterampilan Gerak untuk Anak Usia Dini Taman KanakKanak B. Jendela Olahraga, 2(1), 140-147.

Prahesti, S. I., Taulany, H., \& Dewi, N. K. (2019). Gerak dan Lagu Neurokinestetik (GELATIK) untuk Menumbuhkan Kreativitas Seni Anak Usia Dini. Jurnal Obsesi : Jurnal Pendidikan Anak Usia Dini, 4(1), 162. https://doi.org/10.31004/obsesi.v4i1.289.

Pratiwi, B., \& Puspito Hapsari, K. (2020). Analisis Kemampuan Berpikir Tingkat Tinggi Melalui Pemanfaatan YouTube Sebagai Media Pembelajaran Bahasa Indonesia. Jurnal Ilmiah Sekolah Dasar, 4(2), 282. https://doi.org/10.23887/jisd.v4i2.24238.

Rose, J. A., O'Meara, J. M., Gerhardt, T. C., \& Williams, M. (2016). Gamification: using elements of video games to improve engagement in an undergraduate physics class. Physics Education, 51(5). https://doi.org/10.1088/0031-9120/51/5/055007.

S., T. S., Nasirun, M., \& D, D. (2020). Aplikasi Gerak Lokomotor Sebagai Media Untuk Meningkatkan Kemampuan Motorik Kasar Pada Kelompok B1. Jurnal Ilmiah Potensia, 5(1), 1. https://doi.org/10.33369/jip.5.1.16-24.

Srirahayu, R. R. Y., \& Arty, I. S. (2018). Validitas dan reliabilitas instrumen asesmen kinerja literasi sains pelajaran Fisika berbasis STEM. Jurnal Penelitian Dan Evaluasi Pendidikan, 22(2), 168-181. https://doi.org/10.21831/pep.v22i2.20270.

Sugiyono. (2017). Metode Penelitian Kuantitatif, Kualitataif, dan R\&D. Bandung: Alfabeta.

Tegeh, I. M., Jampel, I. N., \& Pudjawan, K. (2015). Pengembangan Buku Ajar Model Penelitian Pengembangan dengan Model ADDIE. Seminar Nasional Riset Inovatif IV, 208-216.

Tegeh, I. M., \& Kirna, I. M. (2013). Pengembangan Bahan Ajar Metode Penelitian Pendidikan dengan ADDIE Model. Jurnal Pendidikan, 11(1), 16. 
Wijirahayu, S., \& Syarif, M. S. (2019). Pengembangan Multimedia Integratif Bahasa Inggris untuk Siswa di Pendidikan Dasar. Jurnal SOLMA, 8(2), 317. https://doi.org/10.29405/solma.v8i2.3093.

Wulandari, M., Asmawi, M., \& Karnadi, K. (2021). Hubungan Status Gizi dan Aktivitas Bermain melalui Keterampilan Gerak Dasar Anak Taman Kanak-Kanak. Jurnal Obsesi : Jurnal Pendidikan Anak Usia Dini, 5(2), 1706-1717. https://doi.org/10.31004/obsesi.v5i2.965.

Wuryanti. (2016). Pengembangan Media Video Animasi untuk Meningkatkan Motivasi Belajar dan Karakter Kerja Keras Siswa Sekolah Dasar. Jurnal Pendidikan Karakter, 6(2). https://doi.org/10.21831/jpk.v6i2.12055.

Wuryanti, U., \& Kartowagiran, B. (2016). Pengembangan Media Video Animasi Untuk Meningkatkan Motivasi Belajar Dan Karakter Kerja Keras Siswa Sekolah Dasar. Jurnal Pendidikan Karakter, 6(2), 232-245. https://doi.org/10.21831/jpk.v6i2.12055. 